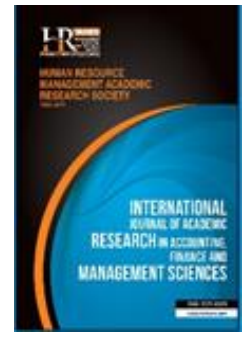

International Journal of Academic Research in Accounting, Finance and Management Sciences

Vol. 9, No.1, January 2019, pp. 142-149

E-ISSN: 2225-8329, P-ISSN: 2308-0337

(C) 2019 HRMARS

www.hrmars.com

To cite this article: Budyastuti T. (2019). Factors that Influence Individual Performance in Sales Accounting Information Systems: Case Study of the Implementation of Indomaret Point of Sales, International Journal of Academic Research in Accounting, Finance and Management Sciences 9 (1): 142-149.

\title{
Factors that Influence Individual Performance in Sales Accounting Information Systems: Case Study of the Implementation of Indomaret Point of Sales
}

Triyani Budyastuti

Accounting Study Program, Faculty of Economics and Business, University of Mercu Buana Jl. Raya Meruya Selatan Kembangan West Jakarta, E-mail: triyani@mercubuana.ac.id

\begin{abstract}
This research is motivated by the existence of an accounting information system, in this case the point of sales, where in theory the implementation of point of sales will improve individual performance in this case Indomaret employees. This study aims to examine the factors that influence individual performance in the sales accounting information system in this case the implementation of point of sales. Population and sample in this study Indomaret employees numbered 100 respondents who had used point of sales. The method used in sample selection is a convenience sampling method where sampling is based on the availability of elements and the ease of obtaining them. Samples are taken/selected because the sample is in the right place and time. The method of data analysis uses smartpls analysis. The results of this study indicate that there is no effect on Usability, Ease of Use, Information Quality and User Satisfaction on individual Performance on the implementation of point of sales.

Key words

Usefulness, Ease of Use, Information Quality, User Satisfaction, Individual Performance

Received: 12 May 2019 (c) The Authors 2019

Revised: 27 May 2019 Published by Human Resource Management Academic Research Society (www.hrmars.com)

Accepted: 10 Jun 2019 This article is published under the Creative Commons Attribution (CC BY 4.0) license. Anyone may reproduce, distribute, translate and create derivative works of this article (for both commercial and non-commercial purposes), subject to full attribution to the original publication and authors. The full terms of this license may be seen at: http://creativecommons.org/licences/by/4.0/legalcode
\end{abstract}

\section{Introduction}

Implementation of information systems for companies in the digital era like now very necessary. The need for companies to process information quickly, right, and accurately makes the company try to implement an information system that fits the needs of the company so that the company will have an advantage competitive and able to compete with other companies.

According to Aldegis (2018) there is an impact for the quality of accounting information systems on the relationship between organizational cultures and accounting information in Jordanian industrial public shareholding companies. Based on the study results, the researchers reached a number of recommendations, including: Organizational culture should receive the attention it deserves, due to its impact on the quality of accounting information systems through enhancing the practices of accounting information system personnel.

With the support of a good information system, companies can improve efficiency and effectiveness, effectiveness is measured by the proper running of business processes, but with higher efficiency in carrying out their business processes, and efficiency can be measured from the shorter time the company needs record stock, or process checkout to customer. With a good system too the company will obtain 
accurate information about the business flow that occurs, because with recapitulation of all transactions that occur in the business, business owners can produce accurate financial statements and income statements, and the company can further processing these data to find out more about marketing strategies and help in their business process problems. For example inventory problems, companies can determine when to re-purchase orders at suppliers, decide to remove items from inventory, and know consumer purchasing patterns.

Point of Sales (POS) system is a network with operations using the main computer that is connected to several POS machine terminals. "Point of Sale (POS) System: A computerized network operated by a main computer and linked to several checkout terminals." Initially, Point of Sales (POS) is the point of sale (Check-out) where the transaction is completed, identical to the place (check-out counter) with the cash register (Cash Register). As the name implies is the point where the customer makes a payment for goods or services, and the seller will issue a receipt for the purchase transaction. POS (point of sales) can provide better services to consumers, as in calculating prices and the number of items purchased can be faster and the quantity of goods no longer depends on manual recording.

Along with the development of the business world, the Point of Sales (POS) function is no longer a selling point, but is a system with various functions such as: dealing with data processing of purchase transactions (Purchases), debt transactions (liabilities), purchase return transactions (purchase returns), and reporting all transactions (reporting) and many other data processes.

Point Of Sales hardware has also evolved to facilitate input-output data on business transactions such as All-In-One Workstations, Back Office Servers, Barcode Scanners, Check Readers (MICRs), Graphical Customer Displays, Handheld Data Collection Devices, Signature Capture Devices, etc.

According to Kosasi (2014) the design of an application point of sale (POS) system can provide better service to consumers, as in calculating prices and the number of items purchased can be faster and the quantity of goods no longer depends on manual recording.

Whereas according to Purwaningsih (2010) the successful implementation of the Online Integrated Service Information System (SIPT) of PT Jamsostek (Persero) is influenced by system quality, information quality, service quality, and user satisfaction and suitability of tasks and technology. The success of implementing SIPT Online is measured by using information system user satisfaction and individual impacts due to the use of information systems.

The research conducted by Syara (2016) Perceived Usefulness has a relationship that is in the opposite direction to the User Satisfaction of Accounting Information Systems. So it can be concluded that Perceived Usefulness has no significant effect on the User Satisfaction of Accounting Information Systems.

As with the research conducted by agus widodo (2016) which states that the quality of information does not significantly influence user satisfaction through trust as validation.

Istianingsih and Utami (2009), using quality variables service, system quality, information quality, user satisfaction and performance individual. The results of the research are service quality, system quality, quality information has a positive and significant effect on user satisfaction, whereas Information system user satisfaction has a positive effect on individual performance.

\subsection{Formulation of the problem}

Formulation of the problems of this study is as follows:

1. Test the effect of perceived usefulness on individual performance

2. Testing the influence of perceived ease of use on individual performance

3. Test the influence of Information Quality on individual performance

\section{Literature review}

\subsection{Technology Acceptance Model (TAM)}

According to Davis (1986) the behavior of using Information Technology (IT) begins with the perception of the benefits (usefulness) and perceptions about the ease of using IT (ease of use). These two elements when associated with TRA are part of Belief. Davis (1986) defines the perception of usefulness based on the definition of useful words, namely capable of being used advantageously, or can be used for 
profitable purposes. Perception of usefulness is a benefit that is believed by individuals that can be obtained when using IT.

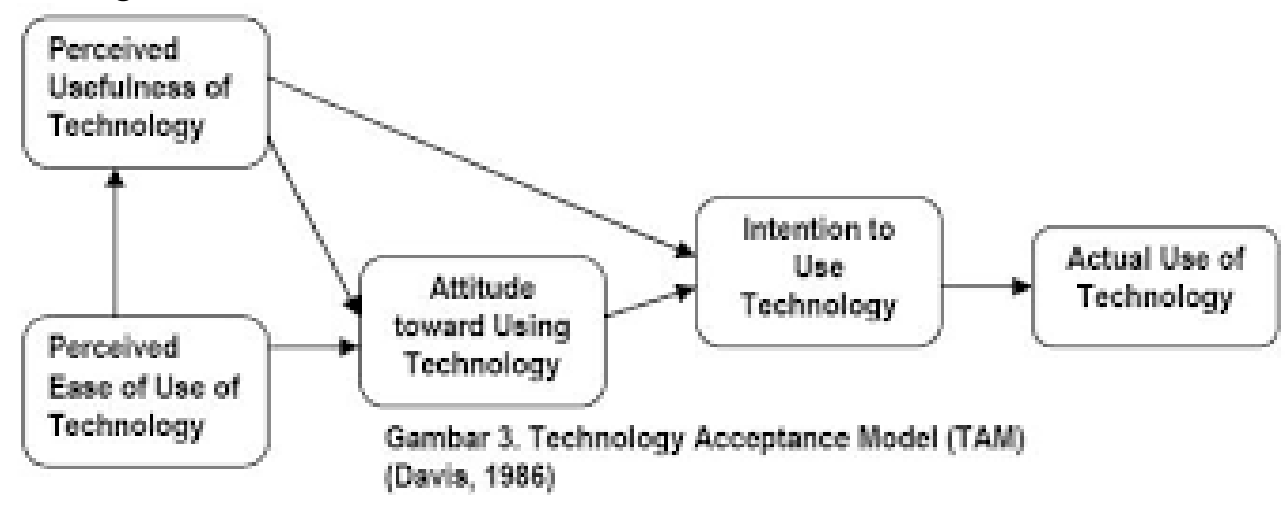

Source: Davis (1986)

Figure 1. TAM Model

\subsection{Unified Theory of Acceptance and Use of Technology (UTAUT)}

UTAUT developed by Venkatesh, et al. (2003) combining features from several theories of acceptance of leading technology into one theory. The results of testing these models finally recommend four variables as determinant of the purpose and use of information technology, namely performance expectations (performance expectancy), business expectations (social expectancy), social influences (Social Influence), and supporting conditions (Facilitating Conditions), and four variables as moderators (moderating variables) between determinants with the purpose and use of information technology, namely gender, age, experience, and voluntariness (compulsory or not using an information system at work).

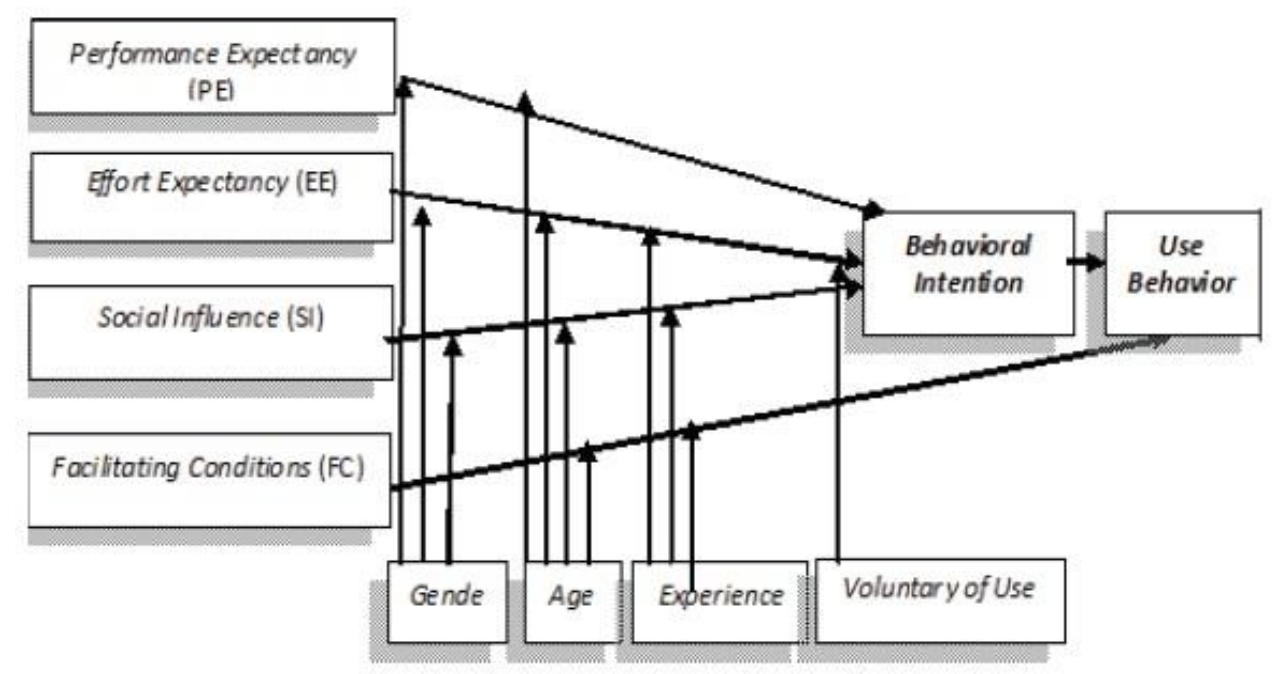

Source: Venkatesh et al. (2003)

\subsection{Point of Sales}

Point of sales or abbreviated as POS in general can be interpreted as a system that allows the holding of the transaction process. POS can be used in all sales transactions such as restaurants, supermarkets, hotels, and retail stores. Therefore, POS can also be interpreted as a transaction service process in a retail store. Of all the definitions explained, it can be concluded that the point of sales can be interpreted as a system that allows the holding of transactions which include the use of the cash register.

According to Rokhman (2012), point of sales (POS) software is software that is widely used in retail businesses such as supermarkets, mini markets, pharmacies, cafes, and others. In general the processes that are usually used at each point of sales system found in companies are as follows: 

1) Point of sales (sales transaction)
2) Inventory control (Control of inventory)
3) Barcode reading
4) Store management
5) Sales Returns
6) Reporting

\subsection{Information Quality}

According to Jogiyanto (2005) the quality of information depends on three things, namely:

a. Accurate (accurate) Information must be free from errors and cannot or be misleading, must clearly reflect the intent

b. Timely (timeliness) Information that comes to the recipient may not be too late.

c. Relevant (relevance) This information has benefits for the wearer.

DeLone and McLean (2003) state that the quality of information measures the quality of the output of information systems, namely the quality produced by information systems, especially in the form of reports. In this study, the information quality variable is represented by X2. The following are indicators of information quality.

1) Accuracy

Bailey and Pearson in Diana Garcia Smith (2007) stated that accuracy is the truth of the information produced by information systems. Information produced by information systems must be accurate because it plays a role for decision making (DeLone and McLean, 2003). Accurate information means having to error free and free of bias.

2) Completeness

Bailey and Pearson in Diana Garcia Smith (2007) state that the completeness of the quality of information is the completeness of the content of information produced by information systems. Complete information is information that includes all information that needed by users of the information system.

3) Format (Shape)

The format/form of information presentation produced by the information system, describes the quality of the information system information. If the presentation of information is in the right form, the information produced is considered quality so that it is easier for users to understand the information produced.

4) Timeliness

The quality of information from information systems can be said to be good if the information produced is on time, if the information needed is too late, then this will affect the speed of decision making, and if decision making is too late it will have fatal consequences for users and organizations.

5) Relevance

The quality of information of an information system is said to be good if it is relevant to the needs of users, if the information produced is relevant, then the information will be useful. The relevance of information for each user is different.

\subsection{Individual Performance}

The organization or company invests a large investment for improve individual or organizational performance with regard to implementation technology in an information system (Salman Jumaili, 2005).

In general, performance (performance) is defined as a level someone's success in performing performance. Goodhue and Thompson's research (1995), achievement of individual performance is stated to be related to achievement a series of individual tasks with information technology support available. This performance measurement looks at the impact of the system on the effectiveness of completion task.

\section{Study Framework}

The frame of mind in this study is to describe the influence between independent variables and the dependent variable as follows: 
According to the research of Dahlia (2017) the perception of individual benefits has a significant positive effect on user satisfaction of e-filing facilities at Pondok Gede KPP.

Research conducted by Agung (2014) Perceived usefulness has a significant effect on end-user satisfaction. SISDM is able to increase effectiveness, improve performance, save time and help complete employee data management quickly.

The relationship between end-user satisfaction of information systems and performance this individual has been tested by DeLone and McLean (2003) in the success model the information system they make. They stated that between the impacts of the use of information systems on individual performance with the level of user satisfaction (user satisfaction) has a reciprocal relationship

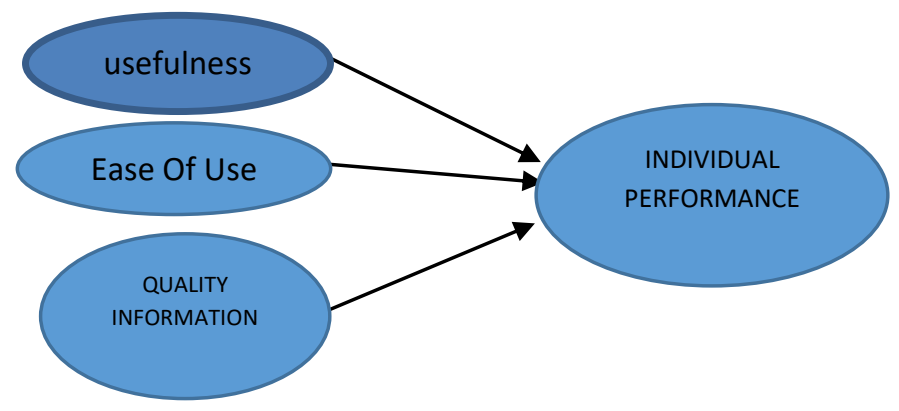

Figure 3. Conceptual Framework

\section{Hypothesis}

Based on the hypothesis model above, the hypothesis formulation can be made as follows:

1. There is a significant influence between usability on the application of point of sales to user satisfaction partially.

2. There is a significant influence between the ease of application of point of sales to user satisfaction partially.

3. There is a significant influence between the qualities of information on the application of point of sales to user satisfaction partially.

\section{Methodology of Research}

\subsection{Research Methods}

This study uses a causal research method which aims to examine the effect, between a variable (Independent/Xn) and other variables (Variable Dependent/Yn). In this case it consists of: $X 1=$ Usefulness, $\mathrm{X} 2=$ Ease of use, $\mathrm{X} 3=$ Quality of Information and $Y=$ Individual Performance. This research requires testing hypotheses with statistical tests.

\subsection{Definition and Operational Variables}

Variables are everything that will be the object of observation in a study in the form of a concept that has a variety of values. In this research, independent variables (dependent variables) and dependent variables (dependent variables, independent variables are:
a) Usefulness (X1) as an Independent variable
b) Ease of Use (X2) as an Independent variable
c) Information Quality (X3) as an Independent variable
d) Individual Performance $(\mathrm{Y})$ as Dependent Variables

\subsection{Research Population and Samples}

Samples are some of the members of the population selected using certain processes so that they can represent the population. The sample selection method used in this study is accidental sampling method, which is the type of sample selection incidentally the researcher encountered, if it was seen the 
subject that happened to be found was suitable for the data source. The sample that the researcher will take is the point of sales user at Indomaret, namely the cashier, which amounts to 100 respondents.

\subsection{Analysis Methods}

Data analysis is a procedure or process of activities within summarizes the data collected from the results of the study so that the data can be processed into a form that is more understandable to the reader. In this study questionnaire analysis using a Likert scale 1-5, using smartPLS3 software (Partical Least Square version 3).

\section{Results and discussions}

Hypothesis testing

a. $\quad$ Convergent Validity Test (Outer Model)

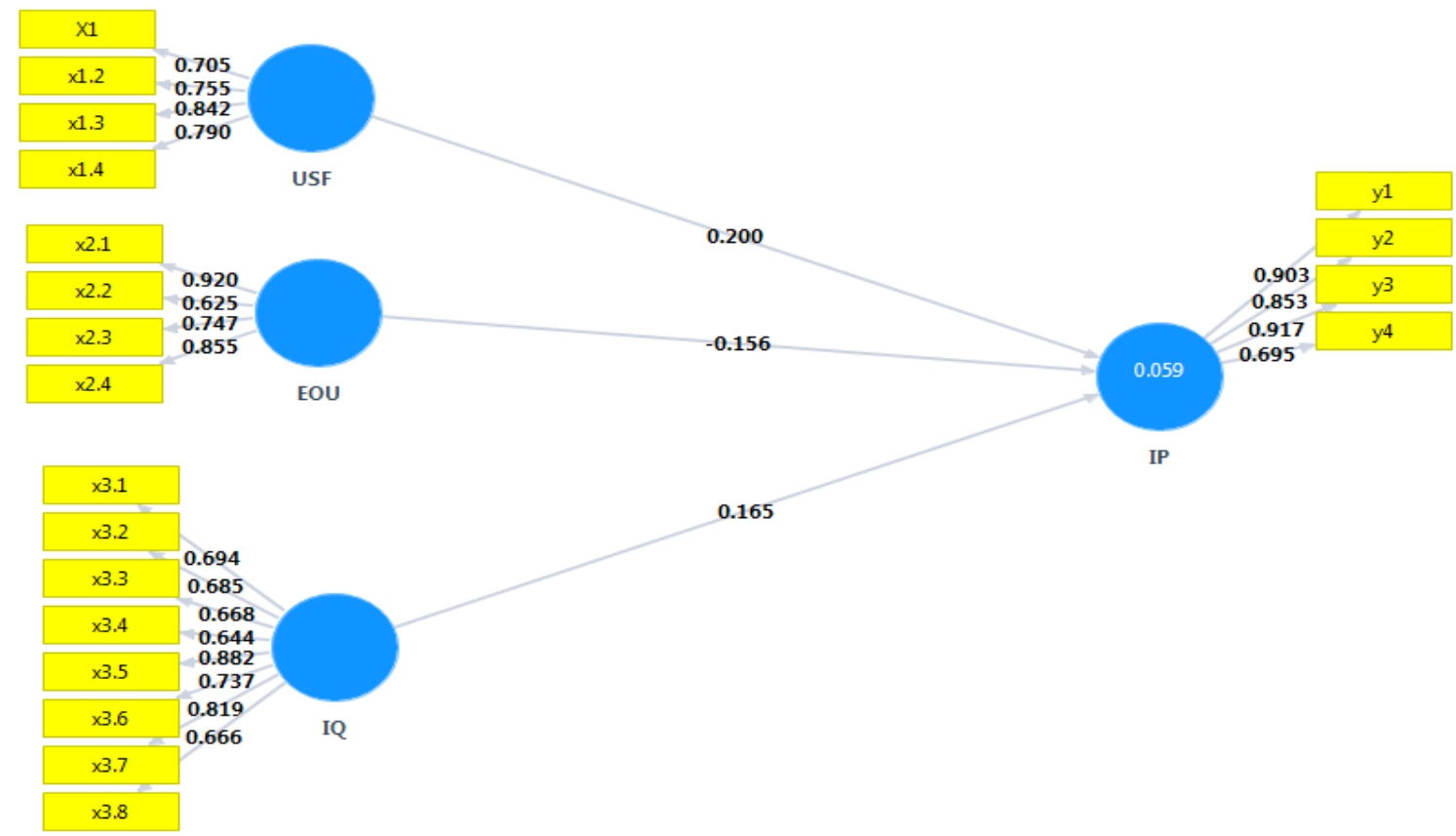

Figure 4. PLS-Algorithm Model after Convergent Validity Test 1

Source: Primary data processed (2019)

Based on the factor loading value above, it meets convergent validity; the indicator value is above 0.5. Another method for assessing discriminant validity is by comparing the square root of average variance extracted (AVE) for each construct with a correlation between constants and other constructs in the model. The model has sufficient discriminant validity if the root AVE for each construct is greater than the correlation between other constructs and constructs.

b. Average Variance Extraced (AVE) - (Outer Model)

Table 1. Average Variance Extracted

Source: Primary data processed (2019)

\begin{tabular}{|c|c|}
\hline Variabel & AVE \\
\hline EOU & 0.632 \\
\hline IP & 0.717 \\
\hline IQ & 0.531 \\
\hline USF & 0.600 \\
\hline
\end{tabular}

A good model is required if the AVE of each other construct is greater than 0.5 (Ghozali, 2014). The output results in the table above show that the AVE value of all variables is greater than 0.50 . 
b. Reliability Test using Composite Realibility and Chronbach Alpha - (Outer Model)

Table 2. PLS Algorithm Models - Composite Realibility and Chronbach Alpha

\begin{tabular}{|c|c|c|}
\hline Variable & Composite Reliability & Cronbachs Alpha \\
\hline EOU & 0.871 & 0.802 \\
\hline IP & 0.909 & 0.868 \\
\hline IQ & 0.900 & 0.882 \\
\hline USF & 0.857 & 0.780 \\
\hline
\end{tabular}

Source: Primary data processed (2019)

The reliability test output results using Compostie Reliability and Chronbach Alpha both because of Composite Reliablity above 0.70 and Chronbach Alpha above 0.6 so it can be concluded that all construct indicators are reliable or meet reliability testing.

R Square Test and Predictive Relevance (Inner Model)

Table 3. PLS Algorithm - R Square \& Predictive Relevance Models

\begin{tabular}{|l|l|}
\hline & R Square \\
\hline IP & 0.030 \\
\hline
\end{tabular}

Source: Primary data processed (2019)

Based on the determination coefficient in the table above, the R2 value of the User Behavior variable is 0.030 , which means that the value can indicate that the User Behavior variable can be explained by the usefulness variable, ease of use and trust by $97 \%$. In this study the adjusted $\mathrm{R} 2$ is $3 \%$ while the remaining $97 \%$ is influenced by other variables not found in the research model.

\section{Path Coofficients}

The next test is the Path Coefficient test to see the significance of Usefulness (USF), Ease of Use (EOU), and Information Quality (IQ) against Individual Performance (IP). To test the hypothesis in this study, the $t$ value of statistics for each pathway is partially directly affected.

The results of this test will show significant results seen from the results of the Original Sample, the value of probability and t-statistics. For probability values, the $p$-value with alpha is $5 \%$. Tests are carried out with limits according to table t. The t-table value for alpha $5 \%$ is 1.96 . to accept the proposed hypothesis is more than 1.96 , which if $t$ table of significance $5 \%$ is in the range of values -1.96 and 1.96 , the hypothesis will be rejected. The results of t-statistical estimation can be seen in the path coefficients.

Table 4. Path Coefficient

\begin{tabular}{|l|c|c|c|c|c|}
\hline & Original sample & Sample Mean & Standard Deviasi & T-Statistics & P Values \\
\hline EOU -> IP & -0.156 & -0.056 & 0.173 & 0.902 & 0.367 \\
\hline IQ -> IP & 0.165 & 0.113 & 0.219 & 0.752 & 0.452 \\
\hline USF -> IP & 0.200 & 0.191 & 0.170 & 1.176 & 0.240 \\
\hline
\end{tabular}

Source: Primary data processed (2019)

In the table above, the path parameters obtained from the effect of Usefulness on Individual Performance are 1.176. The value of $t$ statistics is 1.176 lower than the value of $t$ table 1.96 and $P$ values are 0.240 higher than the significance level $\alpha=0.05(5 \%)$. These results indicate that there is a no significant effect between Usefulness to individual performance (IP). Thus the first hypothesis (H1) which states that Usefulness has a significant effect on individual performance (IP) rejected.

For the relationship between the Ease of Use (EOU) variable on individual performance (IP), the results in the table above show path parameter coefficients with a statistical $t$ value of 0.902 lower than $t$ 
table 1.96 and a $p$ value of 0,367 higher than the significance level $\alpha=0.05(5 \%)$. These results indicate that there is a no significant influence between Ease of Use (EOU) on individual performance (IP). Thus the second hypothesis ( $\mathrm{H} 2)$ which states that the Ease of Use (EOU) has a significant effect on individual performance (IP) is rejected.

For the relationship between the Quality of Information (IQ) variable on individual performance (IP) with a $t$ value of 0.752 (lower than 1.96) and $p$ values at 0.452 higher than the significance level $\alpha=0.05$. These results indicate that there is no significant effect between Quality of Information (IQ) variable on individual performance (IP). Thus, the third hypothesis (H3) which states that Quality of Information (IQ) has a significant effect on individual performance (IP) is rejected.

\section{Conclusions}

From the results of the research above, the researcher can conclude that:

1. Usefulness does not affect individual performance

2. Ease of use does not affect individual performance

3. Quality Information does not affect individual performance

\section{References}

1. Agung, A. D. (2014). Faktor-Faktor Yang Mempengaruhi Kepuasan Pengguna Akhir Sistem Informasi Sumber Daya Manusia (Studi Kasus Di Bpk Ri). Seminar Nasional Teknologi Informasi Dan Multimedia 2014. Stmik Amikom Yogyakarta, 8 Februari 2014

2. Agus, W. D. (2016). Pengaruh Kualitas Sistem Aplikasi Dan Kualitas Informasi Terhadap Kepuasan Pengguna Sistem Aplikasi Rts (Rail Ticketing System) Dengan KepercayaanSebagai Variabel Mediasi (Studi Pada Penumpang "Kai" Ekonomi Operasi 4 Semarang). Media Ekonomi Dan Manajemen Vol. 31 No. 2 Juli 2016

3. Aldegis, A.M. (2018). Impact of Accounting Information Systems' Quality on the Relationship between Organizational Culture and Accounting Information in Jordanian Industrial Public Shareholding Companies, International Journal of Academic Research in Accounting, Finance and Management Sciences, 8 (1): 70-80, http://dx.doi.org/10.6007/IJARAFMS/v8-i1/3829

4. Baridwan, H. (2007). Kualitas Dan Efektivitas Sistem Informasi Berbasis Komputer, Brawijaya: Vol.8, No.2.

5. Dahlia, G., Meida, R. M. (2017). Analisis Pengaruh Kualitas Sistem, Kualitaslayanan, Kualitas Informasi, Kemudahan Penggunaan, Dan Persepsi Manfaat Terhadap Kepuasan Pengguna Fasilitas E-Filing (Studi Kasus : Wajib Pajak Kpp Pratama Pondok Gede). Media Informatika Vol. 16, No. 1

6. DeLone, W., McLean, E.R. (2003). The DeLone and McLean Model of Information System Success: A Ten Year Update. Journal of Management Information Systems.

7. Ghozali, I. (2015). Structural Equation Modeling Metode Alternatif dengan Partial Least Square (PLS). Dilengkapi Software Smart PLS 3.0. XIstart 2015 dan Warp PLS 4.0. Semarang. Badan Penerbit_Undip.

8. Goodhue, D. and Thompson, R. (1995). Task-Technology Fit and Individual Performance. MIS Quarterly (19:2).

9. Imam, M. J., Sundari, J. (2017). Pengaruh Kualitas Sistem Informasi Terhadap Kepuasan Pengguna Pada Sma Al - Huda Cengkareng. Techno.Com, Vol. 16, No. 3, 256-267.

10. Istianingsih, W. (2009). "Pengaruh Kepuasan Pengguna Sistem Informasi terhadap kinerja individu", dalam Simposium Nasional Akuntansi (SNA) volume 12. Universitas Mercubuana.

11. Jogiyanto (2007). Model Kesuksesan Sistem Teknologi Informasi. Yogyakarta: Penerbit ANDI.

12. Purwaningsih, S. (2010). Analisis Kesuksesan Penerapan Sistem Informasi Pada Sistem

13. Informasi Pelayanan Terpadu (Sipt) Online: Studi Pada Pt. Jamsostek (Persero Jurnal Aset, Februari 2010 12, 2. Diambil Dari: Http://Jurnal.Widyamanggala.Ac.Id/Index.Php/Asetwm/Article/View/39.

14. Rokhman, A. (2012). Apa itu software POS. Diambil dari: http://abdulatifrokhman.com/2012/05/ apa-itu-software-pos. (20 Juli 2017)

15. Syara, M. A. (2016). Pengaruh Kualitas Sistem Informasi, Kualitas Informasi, Dan Perceived Usefulness Terhadap Kepuasan Pengguna Sistem Informasi Akuntansi (Studi Pada Pengguna Sistem Informasi Akuntansi Di Rumah Sakit Mata Cicendo Bandung). E-Proceeding Of Management : Vol.3, No.2. 